\title{
LEARNING CHEMISTRY WITH THE "RED AND OX" GAME DURING COVID-19 PANDEMIC AT SMAN 22 SURABAYA
}

\author{
Any Sufiaty ${ }^{*}$, Ryan Hendra Cahyadhi ${ }^{1}$ \\ ${ }^{1}$ Pendidikan Kimia, Fakultas Matematika dan Ilmu Pengetahuan Alam, Universitas Negeri Surabaya \\ *Corresponding author: anysufiaty@yahoo.co.id
}

\begin{abstract}
This study aimed to examine the impact of utilizing "Red and Ox" Game as a learning media while Study From Home. Tests were given before and after the student using this game. After that the student have to fulfill some respons after learning using the game. The results of the study showed this game effectiveness based on classical completeness from 40\% to $100 \%$ and there was a significant difference between the average scores before and after learning, also students respon obtained 87,73\%. From aforementioned data, it can be concluded that learning using Red and Ox Game while Study From Home can have an impact on learning of balancing redox equation. This game also can be used as an alternative for teachers so the learning process will be more friendly.
\end{abstract}

Keywords: game, learning, redox, study.

\section{PENDAHULUAN}

Melalui terbitan surat edaran kemendikbud selama masa darurat Covid-19, dilakukan sistem pembelajaran di rumah, sehingga kegiatan pembelajaran di sekolah ditiadakan. Berdasarkan surat edaran tersebut, selama masa pandemi berlangsung proses pembelajaran dilaksanakan guna memberikan pengalaman belajar bermakna untuk peserta didik (Mendikbud, 2020). Adanya kebijakan tersebut tentunya berdampak bagi guru hingga peserta didik yang diharuskan beradaptasi guna mencari solusi yang sesuai terhadap masalah baru yang muncul, salah satunya ialah kejenuhan peserta didik dalam proses pembelajaran secara daring. Sejak dilaksanakannya pembelajaran daring banyak peserta didik yang mulai merasa jenuh dan berdasarkan angket yang disebarkan kepada 82 peserta didik SMAN 22 Surabaya, mereka mulai merasa jenuh dalam waktu yang berbeda-beda, hanya $8,5 \%$ peserta didik yang menyatakan hingga pemberian angket merasa belum jenuh dan bosan.

Kejenuhan peserta didik dalam proses pembelajaran dihadapi dengan berbagai cara salah satunya yakni menciptakan metode pembelajaran menyenangkan, ciri dari proses pembelajaran yang menyenangkan itu sendiri ialah lingkungan pembelajaran yang rileks dan dapat membuat peserta didik percaya diri dalam mencapai keberhasilannya (Jauhar, 2010). Berdasarkan hasil penelitian sebelumnya, pembelajaran yang menyenangkan dapat dilakukan dengan menggunakan alternatif media pembelajaran permainan (Lutfi dkk, 2019; Lutfi \& Purwandani, 2019). Sejalan dengan hal tersebutl, berdasarkan angket yang disebar kepada peserta didik menyatakan bahwa mereka setuju jika digunakan permainan sebagai media pembelajaran.

Media merupakan perantara guna menyampaikan suatu pesan maupun informasi dari individu ke individu lain (Sadiman dkk, 2014). Dalam pembelajaran, media berguna dalam penyampaian informasi dari guru pada peserta didik, media juga digunakan menarik minat peserta didik untuk berpartisipasi aktif pada proses pembelajaran (Priatmoko dkk, 2012). Salah satu media yang banyak dikembangkan ialah berupa permainan. Dalam angket awal penelitian menunjukkan, frekuensi peserta didik bermain tergambarkaan dalam diagram berikut. 


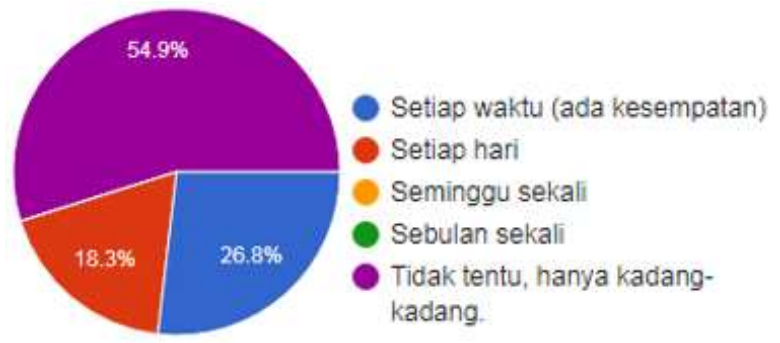

Gambar 1 Frekuensi peserta didik bermain

Berdasar data di atas memperlihatkan semua peserta didik menyukai permainan.

Dan hasil angket lainnya, menunjukkan sebanyak 79,3\% peserta didik mampu bermain hingga satu jam lebih dengan rincian seperti berikut.

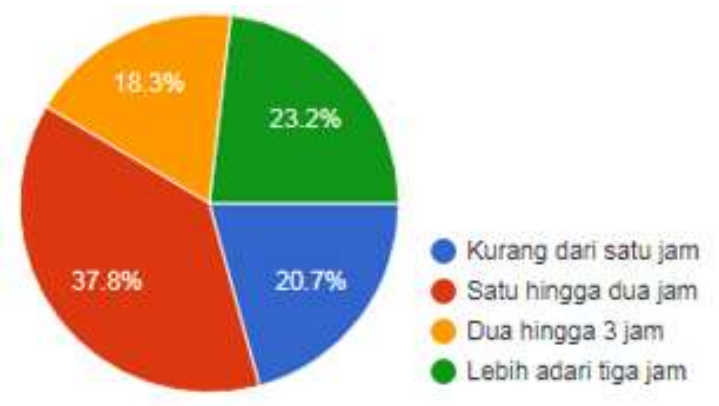

\section{Gambar 2 Ketahanan peserta didik bermain permainan}

Ketahanan peserta didik dalam bermain permainan yang ditunjukkan pada Gambar 2 di atas tentunya dapat dimanfaatkan untuk pempelajaran kimia. Data lain menunjukan pula bahwa sebanyak $91,46 \%$ dari 82 peserta didik merasa setuju jika pembelajaran kimia selama ada wabah covid-19 menggunakan permainan sebagai media pembelajaran.

Ilmu kimia adalah bagian ilmu pengetahuan alam (IPA) yang berfokus mendalami materi serta energi hingga kemungkinan perubahannya ke zat lain. Pemahaman hakekat perubahan kimia atau reaksi kimia bisa dilakukan dengan mendalami hakekat materi. Materi di alam berwujud unsur, senyawa serta campuran. Secara submikroskopis, bentuk ketiga materi terbentuk dari unit atom atau atom-atom, bisa berwujud gabungan atom-atom (molekul) berinteraksi melalui ikatan kimia, sehingga penggunaan media virtual diperlukan (Farida, 2018). Berdasarkan hasil angket yang diberikan, 63 dari 80 peserta didik $(76,8 \%)$ menyatakan bahwa materi reaksi redoks adalah salah satu materi sulit bagi peserta didik, bagian dari materi reaksi redoks ialah penyetaraan reaksi redoks. Dalam perkembangan teknologi seperti sekarang ini, telah dikembangkan banyak media permainan yang dapat digunakan pada smartphone yang dimiliki oleh peserta didik. Permainan sebagai media pembelajaran bertujuan agar peserta didik belajar mandiri dan terciptanya suasana belajar yang rekreatif sehinggga belajar menjadi sesuatu yang menarik untuk peserta didik (Priatmoko dkk, 2012).

Permainan Red dan Ox untuk digunakan sebagai media pembelajaran pada materi penyetaraan reaksi redoks. Permainan ini terdiri dari 3 buah level yang pada tiap-tiap levelnya memiliki fokus latihan soal yang berbeda. Pada awalnya para pemain (peserta didik) dituntut untuk belajar pada materi yang ada di dalam permainan tersebut sebelum mereka bisa menuju level 1 , kemudian setelah memasuki tiap levelnya pemain harus bisa mendapatkan sejumlah kunci yang dibutuhkan agar bisa menuju level selanjutnya. Pada akhir level pemain akan mendapatkan sebuah "artefak" yang berisi sebuah pesan yang dicari oleh si tokoh dalam permainan.

Berdasarkan uraian di atas, pada situasi pembelajaran daring akibat pandemic covid 19 perlu dilakukan pembelajaran kimia dengan memanfaatkan permainan sebagai media pembelajaran. Tujuan penelitian adalah untuk memperoleh tingkat efektifitas penggunaan permainan Red dan Ox sebagai media pembelajaran redoks di SMA Negeri 22 Surabaya.

\section{METODE}

Penggunaan metode pada penelitian ini yakni jenis deskriptif kuantitatif dengan one group pretest posttest design yakni para peserta didik pada awalnya diberikan pretest guna mengukur kemampuan awal mereka serta posttest yang digunakan untuk mengukur kemampuan akhir peserta didik seperti pada gambar berikut (Sugiyono, 2013).

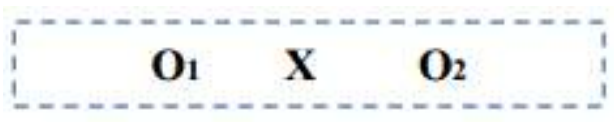




\section{Gambar 3 Desain Penelitian}

Keterangan:

$\mathrm{X}$ : Perlakuan pembelajaran dengan media permainan Red dan Ox

$\mathrm{O}_{1}$ : Skor pretest

$\mathrm{O}_{2}$ Skor posttest

sehingga dapat diketahui dampak yang diberikan oleh permainan Red dan Ox terhadap kemampuan peserta didik. Peserta didik yang diteliti berasal dari SMAN 22 Surabaya yang terdiri dari 30 orang peserta didik yang belum pernah mendapatkan materi penyetaraan reaksi redoks.

Instrumen yang digunakan yakni lembar angket respon, lembar pretest dan lembar posttest. Lembar angket respon digunakan mengetahui tanggapan peserta didik peserta didik setelah menggunakan permainan, lembar pretest dan posttest digunakan untuk mengukur pemahaman materi peserta didik sebelum dan sesudah menggunakan permainan.

Efektifitas yang diukur dari penelitian ini didasarkan pada hasil belajar dan angket respon peserta didik dari penggunaan permainan Red dan Ox. Permainan dinilai berdasarkan angket yang disebarkan kepada peserta didik setelah menggunakan permainan ini dan permainan dikatakan efektif apabila mencapai $\geq 80 \%$. Hasil belajar dinilai atas dasar perbedaan signifikan pada skor rata-rata pretest dan skor posttest hingga tercapainya ketuntasan klasikal, yakni telah mencapai ketuntasan $\geq 85 \%$.

\section{HASIL DAN PEMBAHASAN}

Berdasarkan hasil penelitian, pada proses pembelajaran di rumah peserta didik diberikan permainan yang nantinya akan diinstall di smartphone kemudian ketika bermain, peserta didik akan memberitahukan sampai di mana mereka bermain pada guru disertai bukti foto yang berisi tangkapan layar smartphone masing-masing. Berdasarkan hal tersebut sebanyak 30 orang berhasil menyelesaikan level 1, 28 orang berhasil menyelesaikan level 2 dan 26 orang dari 30 orang peserta didik berhasil menyelesaikan semua level dalam permainan Red dan Ox dimana pada level pertama berfokus pada materi konsep redoks, level kedua pada materi penyetaraan reaksi redoks dengan metode setengah reaksi dan pada level terakhir pada materi penyetaraan reaksi redoks pada materi penyetaraan reaksi dengan metode biloks. Hal ini menunjukkan adanya kesungguhan peserta didik dalam menyelesaikan permainan. Permainan memberikan kondisi di mana ketika peserta didik mampu menjawab soal dengan benar serta dapat melanjutkan ke level selanjutnya maka mereka akan senang sehingga akan menimbulkan respon berulang dan akhirnya masuk pada memori jangka panjang. Masuknya informasi pada memori jangka panjang ini terjadi bilamana hal itu menciptakan rasa senang sehingga proses belajar berjalan tanpa adanya keterpaksaan dari peserta didik.

Kemudian pada angket respon dari 30 peserta didik didapatkan hasil sebagai berikut.

Tabel 1 Aspek Respon Peserta didik

\begin{tabular}{ll}
\hline \multicolumn{1}{c}{ Aspek } & Persentase \\
\hline $\begin{array}{l}\text { Ketertarikan terhadap permainan } \\
\text { sebagai media pembelajaran }\end{array}$ & $77,78 \%$ \\
\hline Kebermanfaatan Permainan & $90 \%$ \\
\hline $\begin{array}{l}\text { Kemudahan dalam } \\
\text { menggunakan permainan }\end{array}$ & $88,33 \%$ \\
\hline
\end{tabular}

Kesesuaian dengan karakteristik $\quad 90 \%$ peserta didik

Media pembelajaran memiliki beberapa fungsi di antaranya ialah fungsi atensi yakni media digunakan untuk menarik serta mengarahkan peserta didik berkonsentrasi pada isi pelajaran (Arsyad, 2011). Permainan dapat digunakan sebagai alternatif media yang mampu menarik perhatian peserta didik agar mereka dapat mempelajari topik atau hal tertentu (Smaldino dkk, 2014). Permainan bersifat rekreatif juga dapat bersifat pedagogik bilamana tujuannya digunakan untuk merangsang proses pembelajaran peserta didik (Antunes, 2012). Pada aspek ketertarikan terhadap permainan sebagai media pembelajaran permainan ini diperoleh persentase sebesar $80 \%$ karena dalam permainan ini peserta didik diarahkan untuk mempelajari materi terlebih dahulu pada awal permainan dan saat memasuki level-levelnya mereka dilatih untuk mengerjakan soal-soal 
terkait materi penyetaraan reaksi redoks. Media Permainan juga harus disusun agar sesuai dengan kebutuhan pembelajaran.

Hasil pretest dan posttest peserta didik secara singkat diuraikan sebagai berikut.

Tabel 2 Hasil Pretest dan Posttest

\begin{tabular}{lcc}
\hline & Pretest & Posttest \\
\hline $\begin{array}{l}\text { Jumlah } \\
\text { Peserta didik }\end{array}$ & 30 & 30 \\
\hline $\begin{array}{l}\text { Nilai } \\
\text { terendah }\end{array}$ & 6,25 & 75 \\
\hline Nilai rata-rata & 53,12 & 88,95 \\
\hline $\begin{array}{l}\text { Nilai } \\
\text { tertinggi }\end{array}$ & 81,25 & 100,00 \\
\hline
\end{tabular}

Persentase ketuntasan klasikal peserta didik dapat dilihat pada gambar 4 berikut.

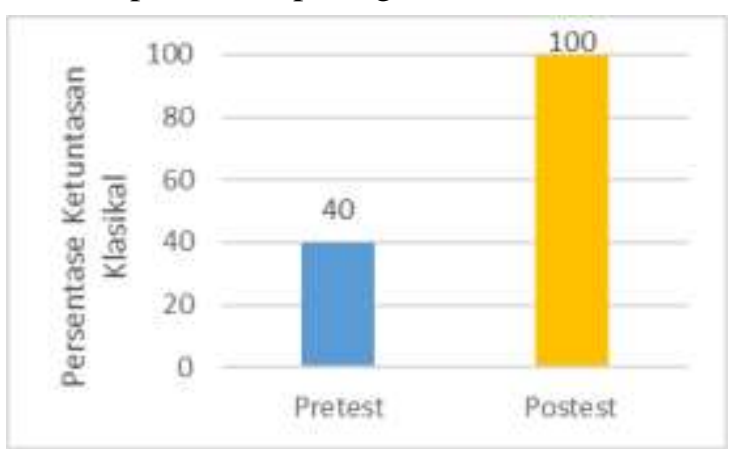

\section{Gambar 4 Ketuntasan Klasikal}

Pada gambar di atas terlihat jikaketuntasan klasikal mengalami peningkatan dari $45 \%$ menjadi $100 \%$. Hal ini terjadi karena peserta didik memahami materi yang penyetaraan reaksi redoks ketika menggunakan permainan Red dan Ox sehingga ketika mereka bermain mereka juga belajar mengkonstruk pengetahuan mereka sendiri (Sadiman dkk, 2012). Dalam permainan red dan Ox terdapat latihan-latihan soal yang dikerjakan oleh peserta didik agar mereka dapat menuju level selanjutnya, jika mereka kesulitan didalam level tersebut juga terdapat materi yang dapat membantu mereka untuk menyelesaikannya. Penggunaan media permainan dalam pembelajaran dinilai bagus karena selain bermain, peserta didik juga dapat belajar dengan lebih menyenangkan dan bisa masuk ke dalam memori jangka panjang mereka dan proses belajarnya lebih bermakna (Trisanti \& I, 2013).
Untuk menunjang data ketuntasan klasikal tersebut dilakukan uji sampel paired ttest untuk mengetahui adanya perbedaan terhadap hasil pretest dan posttest. Sebelum dilaksanakan uji sampel paired t-test terlebih dahulu data pretest dan posttest diuji kenormalannya menggunakan SPSS dan didapatkan hasil berikut.

Tabel 3 Hasil Uji Normalitas Skor Pretest dan Postest

\begin{tabular}{|c|c|}
\hline Skor Pretest & Skor Posttest \\
\hline 30 & 30 \\
\hline $\begin{array}{ll}\text { Kolmogorov- } & 1.261 \\
\text { Smirnov Z } & \end{array}$ & 1.188 \\
\hline $\begin{array}{l}\text { Asymp. Sig. } .083 \\
\text { (2-tailed) }\end{array}$ & .119 \\
\hline $\begin{array}{l}\text { Dari tabel di atas dike } \\
\text { pretest serta posttest terdi } \\
\text { karena diperoleh nilai P-Value } \\
\text { Value adalah sig.) sebesar } 0 . \\
\text { yang keduanya lebih besa } \\
\text { Analisis selanjutnya ialah } \\
\text { Paired Sampel t-test yang mer } \\
\text { kemudian didapatkan hasil seb }\end{array}$ & $\begin{array}{l}\text { ahui jika data } \\
\text { ribusi normal } \\
\text { dalam SPSS P- } \\
50 \text { serta } 0.500 \\
\text { dari } 0.05(\alpha) \text {. } \\
\text { engan metode } \\
\text { ggunakan SPPS } \\
\text { gai berikut. }\end{array}$ \\
\hline \multicolumn{2}{|c|}{ Tabel 4 Hasil Uji Paired Sampel t-test } \\
\hline $\mathbf{T}$ & $\begin{array}{l}\text { Sig. } \\
(2- \\
\text { tailed) }\end{array}$ \\
\hline $\begin{array}{lll}\text { Pair 1 } & \begin{array}{l}\text { skorpretest- } \\
\text { skorpostest }\end{array} & -7.475 \\
\end{array}$ & .000 \\
\hline
\end{tabular}

Pada Tabel di atas dikatakan jika ada perbedaaan skor pada pretest dan posttest karena nilai sig. yang diperoleh sebesar 0.00 yang mana lebih kecil dari $0.05(\alpha)$

Berdasarkan hasil belajar dari data yang diperoleh menunjukan terjadi ketuntasan kelasikal tercapai setelah pembelajaran dan terjadi perbedaan sigifikan pada skor pretest dan skor posttest.

\section{SIMPULAN DAN SARAN}

Simpulan

Berdasarkan uraian di atas disimpulkan jika penggunaan permainan Red dan Ox efektif digunakan sebagai media pembelajaran di tengah wabah Covid-19 yang mengharuskan 
peserta didik belajar di rumah. Keefektifan permainan ini didasarkan pada tercapainya ketuntasan klasikal yang mencapai $100 \%$ dan didukung dengan hasil uji sampel paired t-test yang menunjukkan perbedaan signifikan terhadap skor hasil pretest-posttest dan berdasarkan angket respon peserta didik diperoleh respon sebesar $86,63 \%$.

Saran

Berdasarkan hasil penelitian sertakesimpulan yang dicapai, maka peneliti memberikan saran berupa rekomendasi implikatif dari penelitian ini. Maka para guru hendaknya mempergunakan permainan Red dan Ox sebagai media pembelajaran dalam kondisi belajar di rumah karena mampu membuat peserta didik tertarik dan sesuai dengan karakteristik mereka. Selain itu guru dapat juga memanfaatkan permainan lainnya yang telah memenuhi kelayakan sebagai media pembelajaran.

\section{UCAPAN TERIMAKASIH}

1. Dr. Achmad Lutfi, M.Pd. yang telah mengarahkan dan meluangkan banyak waktu untuk membimbing penulis dalam penyusunan artikel.

2. Kepala sekolah SMAN 22 Surabaya beserta jajarannya yang telah mengizinkan untuk melakukan penelitian.

\section{DAFTAR PUSTAKA}

[1] Antunes, M., Pacheco, M., \& Giovanela, M. 2012. Design and Implementaation of Educational Game for Teaching Chemistry in Higher Education. Journal of Chemical Education, 517-521.

[2] Arsyad, A. 2011. Media Pembelajaran. Jakarta: Rajawali.

[3] Farida, Ida. 2018. Bidang Kajian dan Model-model Penelitian Pendidikan Kimia. Bandung: LP2M. ISBN: 9786025-823411.

[4] Jauhar, M. 2010. Implementasi PAIKEM dari Behavioristik dan Konstruktivistik. Jakarta: Prestasi Pustaka.
[5] Lutfi, A., dkk. 2019. Edutainment with Computer Game as a Chemistry Learning Media. Jurnal Penelitian Pendidikan Sains, 8(2), 1684-1689.

[6] Lutfi, A. \& Purwandani, N, A. 2019. Minat Belajar dan Keberhasilan Belajar Partikel Penyusun Atom Dengan Media Pembelajaran Permainan Chem Man. Jurnal Pembelajaran Kimia, Vol. 4, No. 1, hal. 39-50.

[7] Mendikbud. 2020. Surat Edaran Nomor 4 tahun 2020 tentang pelaksanaan kebijakan pendidikan dalam masa darurat penyebaran Corona Virus Disease. Jakarta: Kementrian Pendidikan dan Kebudayaan.

[8] Priatmoko, S., Saptorini, H.H., Diniy. 2012. Penggunaan Media Sirkuit Cerdik Berbasis Chemo-Edutainment dalam Pembelajaran Larutan Asam Basa. Unesa Journal of Chemical Education. 37-42.

[9] Sadiman, A., R. Rahardjo, Anung, H., \& Rahardjito. 2014. Media Pendidikan: Pengertian, Pengembangan, dan Pemanfaatannya. Jakarta: PT. Raja Grafindo Persada.

[10] Sadiman, Arief S., Rahardjo, R., Haryono, Anung., Rahardjito. 2012. Media pendidikan: pengertian, pengembangan, dan pemanfaatannya. Jakarta: PT Raja Grafindo Persada.

[11] Smaldino, S., Lowther, D., \& Russel, J. 2014. Instructional Technology and Media for Learning: Teknologi dan Media untuk Belajar. Jakarta: Kencana.

[12] Sugiyono. 2013. Metode Penelitian Pendidikan Pendekatan Kuantitatif, Kualitatif dan $R \& D$. Bandung: ALFABETA.

[13] Trisanti, D. C., \& I Gusti Made Sanjaya, M. 2013. Pengembangan media permainan stoichio game pada materi pokok konsep mol bagi peserta didik SMA sekolah. Unesa Journal of Chemical Education, Vol.2 No.2 pp. 181187. 